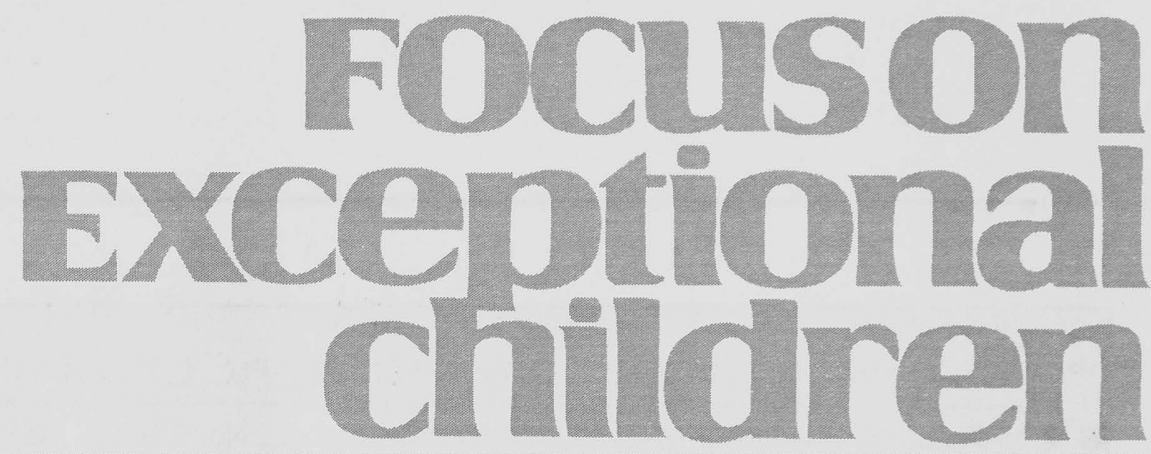

\title{
The U.S. Supreme Court and Parental Rights under the Individuals with Disabilities Education Act
}

\author{
Terrye Conroy, Mitchell L. Yell, Antonis Katsiyannis, and Terri S. Collins
}

President Gerald Ford signed the Education for All Handicapped Children Act (EAHCA) into law in 1975. Since the original passage of the EAHCA, the law has been amended four times and renamed the Individuals with Disabilities Education Act (IDEA) (See Figure 1). After each revision, the U.S. Department of Education has issued new regulations implementing the Act (IDEA Regulations, 34 C.F.R. $§ 300$ et seq). The current IDEA, as amended, is codified in Title 20 of the United States Code (IDEA, 20 U.S.C. $\S \S$ 1400 et seq.).

When the EAHCA was being written, the law's authors recognized the importance of parents being involved in the development of their child's program of special education. In fact, parental involvement has been one of the cornerstones of the law (Yell, Ryan, Rozalski \& Katsiyannis, 2009). In 2004 Congress emphasized the necessity of meaningful parental involvement in the IDEA's findings and purpose section:

\begin{abstract}
Almost 30 years of research and experience has demonstrated that the education of children with disabilities can be made more effective by-strengthening the role and responsibility of parents and ensuring that families of such children have meaningful opportunities to participate in the education of their children at school and at home. (IDEA 20 U.S.C. $\$ 1400$ (c)(5)(B))
\end{abstract}

Congress believed that access to a free appropriate public education (FAPE) for students with disabilities in part depended on their parents' ability to advocate on their child's behalf. One purpose of the EAHCA, therefore, was to create specific procedural safeguards for parents to ensure that their children would receive a FAPE (Meade \& Paige, 2008). See Table 3 for a list of these safeguards.

\section{CLAIMS UNDER IDEA AND THE FEDERAL COURT SYSTEM}

Federal law provides that federal courts have jurisdiction for civil claims arising under the laws of the United States (28 U.S.C. $§ 1331$ (2006)). Thus, the federal courts have jurisdiction over claims under IDEA. IDEA allows an aggrieved party, after exhausting his or her remedies under the Act, to file a claim in state court or a federal district court

Dr. Conroy is a law librarian and legal research instructor at the University of South Carolina School of Law Dr. Yell is the Fred and Francis Lester Chaired Professor of Teacher Education at the University of South Carolina. Dr. Katsiyannis is a professor of special education at Clemson University. Dr. Collins is an assistant professor of special education at the University of North Carolina at Wilmington. 
Education for All Handicapped Children Act of 1975, Pub. L, No, 94-142, 89 Stat. 773 (1975).

Handicapped Children Protection Act of 1986, Pub. L. No. 99-372, 100 Stat. 796(1986).

Individuals with Disabilities Education Act of 1990, Pub. L. No. 101-476, 104 Stat.110 (1990).

Individuals with Disabilities Education Act Amendments of 1997, Pub. L. No. 105-17, 111 Stat. 37 (1997).

Individuals with Disabilities Education Improvement Act of 2004, Pub. L. No. 108-446, 118 Stat. 2647(2004).

\section{FIGURE 1 \\ Legislative History of IDEA}

$(\S 1415(1)(2)(A))$. Because claims under IDEA present a federal question, if a claim is filed in state court, the defendant may remove the claim to a federal district court as a matter of right (28 U.S.C. § 1441(2006)).

In the American judicial system, the lowest federal court is the U.S. district court. After a claim under IDEA goes

\section{Focuson Exceptional children}

ISSN 0015-511X FOCUS ON EXCEPTIONAL CHILDREN (USPS 203-360) is published monthly except June, July, and August as a service to teachers, special educators, curriculum specialists, administrators, and those concerned with the special education of exceptional children. This publication is annotated and indexed by the ERIC Clearinghouse on Handicapped and Gifted Children for publication in the monthly Current Index to Journals in Education (CIJE) and the quarterly index, Exceptional Children Education Resources (ECER). The full text of Focus on Exceptional Children is also available in the electronic versions of the Education Index. It is also available in microfilm from Serials Acquisitions, National Archive Publishing Company, P.O. Box 998, Ann Arbor, MI 48106-0998. Subscription rates: individual, \$48 per year; institutions, \$66 per year. Copyright @ 2010 , Love Publishing Company. All rights reserved. Reproduction in whole or part without written permission is prohibited. Printed in the United States of America. Periodical postage is paid at Denver, Colorado. POSTMASTER: Send address changes to:

Love Publishing Company

Executive and Editorial Office P.O. Box 22353

Denver, Colorado 80222

Telephone (303) 221-7333

\section{CONSULTING EDITORS}

Steve Graham Vanderbilt University
Ron Nelson

University of Nebraska-Lincoln
Eva Horn

University of Kansas through the due process hearing and/or state level hearing, either party may appeal the decision to U.S. District Court. Each state has between one and four U.S. District Courts. A decision at the district court level has authority in the jurisdiction of that court. For example, a decision by the U.S. District Court in South Carolina has authority over the entire state of South Carolina because there is only one federal district court in the state. On the other hand, North Carolina has three U.S. District courts (middle district, eastern district, and western district). A decision by the district court for the middle district of North Carolina has authority only in the middle district.

Following a decision at this level, a party may appeal the decision of the district court to the U.S. Circuit Court of Appeals, also called the appellate court. Thirteen circuits comprise the U.S. courts of appeals (28 U.S.C. $\S 1295$ (2006)). The appellate court has jurisdiction over a larger area than does a district court. So, for example, if an IDEA case were appealed from the U.S. District Court of South Carolina, the case would be heard by the U.S. Court of Appeals for the Fourth Circuit. The U.S. Court of Appeals for the Fourth Circuit has jurisdiction over the states of Maryland, North Carolina, South Carolina, Virginia, and West Virginia.

A ruling from the 13 circuits can be appealed to our court of last resort-the United States Supreme Court (28 U.S.C. $\$ 1254$ (2006)). Filing an appeal is referred to as filing a writ of certiorari. The U.S. Supreme Court determines whether the court will hear a case, called granting certiorari. If the case is heard, the ruling of the U.S. Supreme Court is the law of the land. Because one of the primary purposes of certiorari jurisdiction is uniformity among federal courts of appeals, the U.S. Supreme Court often grants certiorari when decisions of federal courts of appeal conflict on the same matter of federal law. Although Supreme Court Rule10 states that such review by the Court is a matter of judicial discretion and will be granted only for "compelling reasons," subsection (a) provides that, in exer- 
cising its discretion, the Court will consider that a U.S. court of appeals decision is in conflict with another U.S. court of appeals decision on the "same important matter" (Gressman, Gell, Shapiro, Bishop, \& Hartnett, 2007).

Rulings of the U.S. Supreme Court interpreting federal laws such as IDEA settle such conflicts by setting precedent that, according to the common law doctrine of stare decisis, must be followed by every state and federal court in the United States (Black's Law Dictionary, 2009, p. 1537). Since the EAHCA was enacted in 1975, the United States Supreme Court has decided 11 cases affecting parental rights and IDEA, four of which were decided since 2005 (See Table 1). In this article we discuss the most recent of these cases.

\section{FREE APPROPRIATE PUBLIC EDUCATION (FAPE)}

A key purpose of IDEA is to ensure a FAPE is provided to all students with disabilities who are eligible for special

\section{TABLE 1 \\ U.S. Supreme Court Cases Affecting Parental Rights}

\section{Case Name}

Board of Education v.

Rowley, 458 U.S. 176 (1982).

Irving Independent School

District v. Tatro,

468 U.S. 883 (1984).

Smith v. Robinson, 468 U.S. 992 (1984).

\section{Town of Burlington v.}

Department of Education, 471 U.S. 359 (1985).

Honig v. Doe, 484 U.S. 305 (1988).

\section{Florence County School}

District Four v. Carter,

510 U.S. 7 (1993).

\section{Cedar Rapids Community} School District v. Garret F., 526 U.S. 66 (1999).

Schaffer v. Weast, 546 U.S. 49 (2005).

\section{Arlington Central School} District Board of Education v. Murphy, 548 U.S. 291 (2006).

\section{Winkelman v. Parma City}

School District,

550 U.S. 516 (2007).

\section{Decision/Holding}

An IEP is adequate to provide a child with a FAPE if the state has complied with IDEA procedures and the IEP is reasonably calculated to enable the child to receive educational benefits.

Parents are entitled to a related service for their child if the service is a supportive service and not a medical service (other than for diagnosis or evaluation) that must be provided by a licensed physician.

Parents must exhaust their administrative remedies under IDEA before commencing a civil action in court. The EAHCA (now IDEA) was amended the next year to include an exhaustion of administrative remedies requirement $(\$ 1415(I))$.

Courts may award parents reimbursement for the cost of private school as "relief as the court determines appropriate" under IDEA when the public school fails to provide a FAPE and private school placement is appropriate.

The stay-put provision of IDEA applied during the pendency of disciplinary review proceedings, without an emergency exception for dangerous behaviors. IDEA was later amended to include 45-day unilateral alternative placements for certain behaviors.

Courts may award parents reimbursement for the cost of private school when the public school proposes an inappropriate IEP and the private school provides an appropriate education but does not meet state standards.

Affirmed its ruling in Tatro, holding that one-on-one nursing services are included as a related service under IDEA. IDEA does not include a hardship exemption for related services based on cost.

Parents have the burden of persuasion in an administrative hearing challenging an IEP whenever they are the party seeking relief.

Parents who prevail in an IDEA action may not recover expert witness fees as part of their costs under 20 U.S.C. $\S 1415(i)(3)(B)$ of IDEA.

Parents can prosecute their own IDEA claims in federal court pro se (without an attorney) because IDEA grants parents independent, enforceable rights relating to procedural and reimbursement matters as well as entitlement to a free appropriate public education for their child.

Courts may reimburse parents for the cost of private school if all criteria are met even when their child has not previously received special education services from the public school system. 
education services (§ 1400(d)(1)(A)). IDEA defines a FAPE as special education and related services at public expense in compliance with state educational agency standards and the child's individualized education program (IEP) ( $\$ 1401$ (9)). Two U.S. Supreme Court cases, 25 years apart, illustrate the development of the role of parents in the provision of a FAPE for their children. They are Board of Education v. Rowley (1982) and Winkelman v. Parma City School District (2007).

\section{Board of Education of Hendrick Hudson Central School District v. Rowley (1982)}

In 1982, in its first ruling interpreting the EAHCA, the U.S. Supreme Court in Board of Education v. Rowley set the standard for determining whether an IEP is adequate to provide a child with a FAPE. In ruling that a sign language interpreter was not required for Amy Rowley, the Court reasoned that an appropriate education is one that provides meaningful access to public education and that meaningful means an education sufficient to confer some educational benefit (Yell, Katsiyannis, \& Hazelkorn, 2007). In Rowley the High Court established a two-part test for courts to use in reviewing IDEA disputes: "(1) Has the state complied with the procedures set forth in the IDEA; and (2) Is the IEP reasonably calculated to enable the child to receive educational benefits" (Board of Education v. Rowley, 1982, pp. 206-207).

Rather than impose a precise definition of what constitutes an appropriate education on the states, the Supreme Court focused on the protections provided by the procedural safeguards in the EAHCA "giving parents and guardians a large measure of participation at every stage of the administrative process" (Board of Education v. Rowley, 1982, p. 205). The Court reasoned that:

\begin{abstract}
entrusting a child's education to state and local agencies does not leave the child without protection. Congress sought to protect individual children by providing for parental involvement in the development of state plans and policies ... and in the formulation of the child's individual education program... As this very case demonstrates, parents and guardians will not lack ardor in seeking to ensure that handicapped children receive all the benefits to which they are entitled by the Act. (Board of Education v. Rowley, 1982, p. 208)
\end{abstract}

It was obvious that the justices on the highest court in the U.S. believed that parental participation in the IEP process was extremely important.

\section{Winkelman v. Parma City School District (2007)}

On May 21, 2007, the U.S. Supreme Court ruled on the case Winkelman v. Parma City School District. In this case, the high court addressed the rights of parents under IDEA to pursue claims on their own behalf in federal court, without an attorney.

\section{Facts of the Case}

Jacob Winkelman was a 6-year-old boy with autism spectrum disorder whose parents disagreed with the Parma City School District's proposed IEP that would have placed Jacob in a public elementary school. After requesting an impartial due process hearing claiming that the school district failed to provide Jacob with a FAPE and after unsuccessfully appealing the hearing officer's decision in favor of the school district to a state-level review officer, Jacob's parents filed a complaint on their own behalf and on behalf of Jacob to the U.S. District Court for the Northern District of Ohio. Their complaint alleged that the school district failed to follow procedures mandated by IDEA and failed to provide Jacob with a FAPE. The Winkelmans sought a reversal of the hearing officer's administrative decision for the school district. The federal district court ruled in favor of the school district based on the administrative record (Winkelman v. Parma City School District, 2005). The parents appealed to the U.S. Court of Appeals for the Sixth Circuit.

In their appeal to the Sixth Circuit, the Winkelmans argued that the ruling of the U.S. Court of Appeals for the First Circuit's in Maroni v. Pemi-Baker Regional School District (2003) that parents could assert IDEA claims on their own behalf because the Act conferred joint rights upon both parent and child. The Sixth Circuit court disagreed, however, relying on its reasoning in Cavanaugh v. Cardinal Local School District (2005) and dismissed the Winkelmans' appeal until they obtained counsel for their son Jacob (Winkelman v. Parma City School District, 2005, p. 407).

In its Cavanaugh decision that same year, the Sixth Circuit held that IDEA did not grant parents the right to represent their child in federal court without committing the unauthorized practice of law, nor could parents pursue their own substantive IDEA claim without an attorney, which is called pro se representation, because the Act did not grant parents a substantive right to have their child receive a FAPE (2005). Although clearly under IDEA the eligible child has the right to receive a FAPE, the court held that the child's parents did not have this right for their child.

\section{The Unauthorized Practice of Law \& Pro Se Representation}

The Sixth Circuit held that Jacob's parents had engaged in the unauthorized practice of law or pro se representation. The unauthorized practice of law has been defined as "the practice of law by a person, typically a nonlawyer, who has not been licensed or admitted to practice in a given jurisdiction." The practice of law includes "conducting cases in court." The term pro se refers to "one who represents oneself in a court proceeding without the assistance of a lawyer" (Black's Law Dictionary, 2009, p. 1341). 
Jacob's parents appealed the Sixth Circuit's decision to the U.S. Supreme Court. The U.S. Supreme Court granted certiorari to settle the disagreement among the Courts of Appeals (See Table 2) regarding the rights of nonattorney parents to prosecute IDEA actions in federal court.

\section{The Supreme Court}

On May 21, 2007, the U.S. Supreme Court ruled that the Sixth Circuit Court of Appeals erred in dismissing the Winkelmans's appeal for lack of counsel because "IDEA grants parents independent, enforceable rights" including not only rights related to certain procedural and reimbursement matters but also the "entitlement to a free appropriate public education" for their child (Winkelman v. Parma City School District, 2007, p. 533).

Justice Kennedy delivered the opinion of the Court. The question presented was whether nonattorney parents could proceed in federal court without an attorney, either on their own behalf or as representatives of their child. Justice Kennedy explained that, to resolve the issue, the Court needed to examine the provisions of IDEA to determine whether the Act gives parents rights of their own that they can pursue in court or whether it allows them, because of their status as parents, to represent their child (p. 520); and, that the answer lay in interpreting IDEA's entire statutory scheme, beginning with one of the purposes of the Act- "to ensure that the rights of children with disabilities and parents of such children are protected" (Winkelman v. Parma City School District, 2007, p. 523).

In its analysis of the IDEA's procedural safeguards, the Court characterized the parental right to a FAPE as follows:

\begin{abstract}
A central purpose of the parental protections is to facilitate the provision of a "free appropriate public education," $\S 1401(9)$, which must be made available "in conformity with the [IEP]," $\$ 1401(9)(D)$. The Act defines a "free appropriate public education" pursuant to an IEP to be an educational instruction "specially designed ... to meet the unique needs of a child with a disability," $\$ 1401(29)$, coupled with any additional "related services" that are required to assist a child with a disability to benefit from [that instruction]," $\$ 1401(26)(A)$. See also $\$ 1401(9)$. (p. 524)
\end{abstract}

As noted by Justice Kennedy in the Supreme Court opinion, federal law (28 § U.S.C. 1654 (2006)) specifically allows a party to represent his or her own interests (to proceed pro se) in federal court. The problem faced by the Winkelmans was that the Sixth Circuit Court of Appeals held they could not proceed on their own behalf without an attorney because IDEA did not give them substantive rights as parents to a FAPE for their child, and, because they were not attorneys, they could not practice law by representing their child's rights in court. Upon examining both the text and structure of IDEA, the Supreme Court concluded that IDEA conveys enforceable rights upon parents as well as their children; that such rights continue beyond the administrative stage entitling a parent to be a "party aggrieved" in federal court (p. 527); and that those rights encompass procedural, reimbursement, and substantive matters, that is, the right to a FAPE for their child (p. 533).

\section{PARENTAL RIGHTS \& THE SUPREME COURT}

In Winkelman v. Parma City School District (2007), Justice Kennedy outlined various provisions of IDEA that

TABLE 2

\section{Circuit Split on Nonattorney Parents \& the Unauthorized Practice of Law pre Winkelman}

\begin{tabular}{|c|c|c|}
\hline Circuit & Opinion & Position \\
\hline First Circuit & $\begin{array}{l}\text { Maroni v. Pemi-Baker Regional School } \\
\text { District, } 346 \text { F. 3d } 247 \text { (1st Cir. 2003). }\end{array}$ & $\begin{array}{l}\text { Parents were "parties aggrieved" and could sue pro se } \\
\text { for substantive and procedural matters. }\end{array}$ \\
\hline Second Circuit & $\begin{array}{l}\text { Wenger v. Canastota Central School } \\
\text { District, } 146 \text { F. 3d } 123 \text { (2nd Cir. 1998). }\end{array}$ & $\begin{array}{l}\text { Parent who was not attorney could not appear pro se } \\
\text { on behalf of his son. }\end{array}$ \\
\hline Third Circuit & $\begin{array}{l}\text { Collinsgru v. Palmyra Board of Education, } \\
161 \text { F. 3d } 225 \text { (3rd Cir. 1998). }\end{array}$ & $\begin{array}{l}\text { Nonattorney parents had no right to represent child and } \\
\text { lacked substantive rights of their own. }\end{array}$ \\
\hline Sixth Circuit & $\begin{array}{l}\text { Cavanaugh v. Cardinal Local School } \\
\text { District, } 409 \text { F. 3d } 753 \text { (6th Cir. 2005). }\end{array}$ & $\begin{array}{l}\text { Nonattorney parents could not represent their child and } \\
\text { did not share the right to a FAPE with their child. }\end{array}$ \\
\hline Seventh Circuit & $\begin{array}{l}\text { Mosely v. Board of Education of Chicago, } \\
434 \text { F. 3d } 527 \text { (7th Cir. 2006). }\end{array}$ & $\begin{array}{l}\text { Parent could sue for her own procedural rights but not } \\
\text { substantive rights of her child. }\end{array}$ \\
\hline Eleventh Circuit & $\begin{array}{l}\text { Devine v. Indian River County School } \\
\text { Board, } 121 \text { F. 3d } 576 \text { (11th Cir. 1997). }\end{array}$ & $\begin{array}{l}\text { Nonattorney parent did not have the right to represent } \\
\text { his son. }\end{array}$ \\
\hline
\end{tabular}


"mandate or otherwise describe parental involvement" in four areas: (1) procedures for developing a child's IEP, (2) criteria governing the sufficiency of the child's education, (3) mechanisms for review when objecting to the IEP or other IDEA proceedings, and (4) reimbursement of expenses (Winkelman, 2007, p. 523) (See Table 3).

Following is a discussion of United States Supreme Court decisions affecting parental rights since the passage of the EAHCA in 1975 (IDEA) in the four categories outlined by the Supreme Court in Winkelman.

\section{(1) PROCEDURES TO BE FOLLOWED WHEN DEVELOPING A CHILD'S IEP}

In the Winkelman case, the U.S. Supreme Court outlined the procedures mandated by IDEA when developing a child's IEP (See Table 3). The court's opinion also cited its 2005 decision in Schaffer $v$. Weast, which stressed the significant role that parents play in the IEP process. We next briefly examine the U.S. Supreme Court's decision in this case.

\section{Schaffer v. Weast (2005)}

The Schaffer $v$. Weast (2005) decisions placed the burden of persuasion on parents challenging the sufficiency of their child's IEP. Many scholars have considered this case to be a setback for parents of students with disabilities (Meade \& Paige, 2008), except for the High Court's focus on the significance of parental involvement in the IEP process under IDEA (Winkelman, 2007, p. 524). In the Schaffer decisions, Justice O'Conner wrote, "the core of the statute, however, is the cooperative process that it establishes between parents and schools" (Schaffer v. Weast, 2005, p. 53).

\section{2) CRITERIA GOVERNING THE SUFFICIENCY OF AN EDUCATION PROVIDED TO A CHILD}

One of the main purposes of IDEA is to assist states in providing a FAPE for all children with disabilities and to ensure that the rights of children with disabilities and their parents are protected in the process $(\$ 1400(d)(1)(A)-(C))$. To receive federal funds under the Act, states must demonstrate that they have a framework in place to accomplish these goals ( $\S 1411-1412)$. IDEA defines FAPE to include special education and related services $(\$ 1401(9))$. Special education is defined as "specially designed instruction, at no cost to parents, to meet the unique needs of a child with a disability" ( $\$ 1401(29))$. Related services, which are often an important components of a student's FAPE, are described as "transportation, and such developmental, corrective, and supportive services ... as may be required to assist a child with a disability to benefit from special education" (§ 1401(26)).

\section{(3) MECHANISMS FOR REVIEW WHEN OBJECT- ING TO THE IEP OR OTHER IDEA PROCEEDINGS}

IDEA ensures a FAPE for all students with disabilities who are determined to be eligible for special education services $(\S 1400(d)(1)(A))$. The heart of a student's FAPE is his or her individualized education program (IEP) ( $(1414(d))$. The law also contains procedural safeguards by which parents can challenge the school district's proposed IEP if they believe it to be insufficient. Ultimately, if parents and school district officials cannot settle their differences, IDEA provides for an impartial due process hearing ( $(1415(f))$. IDEA does not, however, assign the burden of persuasion at such a due process hearing to any particular party.

\section{The Burden of Proof}

To prevail in a legal proceeding, after both sides have presented their evidence, the party with the burden of persuasion must have convinced the trier of fact (e.g., the due process hearing officer or judge) of the existence of certain facts (Mueller \& Kirkpatrick, 2003). The burden of persuasion is important because the party who is allocated the burden will lose if the hearing officer or judge is not persuaded by the evidence they present. The burden of persuasion becomes particularly significant when the trier of fact is uncertain how to rule because the evidence presented by both sides is equally convincing (McCormick, 1999).

\section{Schaffer v. Weast (2005)}

In Schaffer v. Weast (2005), the Supreme Court addressed the issue of which party would bear the burden of persuasion in a due process hearing when an IEP is challenged under IDEA.

Brian Schaffer was a student with learning disabilities (LD) and a speech-language impairment. Brian's parents believed that the middle school placement offered by the Montgomery County Public School System (MCPS) lacked the smaller classes and intensive services that Brian needed; therefore, they enrolled him in a private school and initiated a due process hearing seeking compensation from the MCPS for their private school expenses (Schaffer $v$. Weast, 2005, p. 533). The administrative law judge (ALJ) who presided over the hearing determined that the evidence presented by the parties at the hearing was equally compelling; therefore, his ruling would depend on which party bore the burden of persuasion. After deciding that the burden of persuasion belonged to Brian's parents because they challenged the IEP, the ALJ found that the Schaffers had not met their burden and ruled in favor of the school district. Brian's parents appealed the ALJ's ruling to the U.S. District Court in Maryland. The district court reversed the ALJ's decision, finding that the 
TABLE 3

U.S. Supreme Court in Winkelman: Parental Rights Under IDEA

\begin{tabular}{ll}
\hline Parental Rights & Statutory Provision \\
\hline Procedures to be followed when developing a child's IEP & \\
School district must develop an IEP for each child with a disability. & $\S 1412(\mathrm{a})(4) \& 1414$ (d) \\
Parents must play a significant role. & Schaffer v. Weast, 546 U.S. 49 (2005). \\
Parents serve as members of the IEP team. & $\S 1414(\mathrm{~d})(1)(\mathrm{B})(\mathrm{i})$ \\
Concerns of parents must be considered by the IEP team. & $\S 1414(\mathrm{~d})(3)(\mathrm{A})(\mathrm{ii})$ \\
$\begin{array}{l}\text { The IEP team must revise the IEP when appropriate to address certain } \\
\text { information by the parents. }\end{array}$ & $\S 1414$ (d)(4)(A) \\
$\begin{array}{l}\text { States must ensure that parents serve as part of any group making } \\
\quad \text { placement decisions for their child. }\end{array}$ & $\S 1414(\mathrm{e})$
\end{tabular}

\title{
General procedural safeguards
}

States must develop procedures to guarantee safeguards regarding the provision of a FAPE.

Parents must be provided an opportunity to examine all relevant records.

$\S 1415(a)$

$\S 1415(\mathrm{~b})(1)$

\section{Criteria governing the sufficiency of an education provided to a child}

A central purpose of the parental protections is to facilitate the provision of a FAPE.

The Act defines "free appropriate public education" as special education and related services that are provided in conformity with the IEP.

Special education means specially designed instruction ... to meet the needs of a child with a disability.

Related services are coupled with specially designed instruction to assist a child with a disability to benefit from that special education.

Special education and related services must be provided under public supervision and direction; meet the standards of the State educational $\S 1401(9) \& \S 1401(9)(D)$ agency; and include an appropriate preschool, elementary school, or secondary school education in the state involved at no cost to the parents.

\section{Mechanisms for review when objecting to the IEP or other IDEA proceedings}

Parents must be given the opportunity to present a complaint if they object to the identification, evaluation, placement, or provision of a FAPE for their child.

The process of review begins with a preliminary meeting where parents may discuss their complaint and the local education agency is provided the opportunity to resolve the matter.

If the complaint is not resolved to their satisfaction, parents may request an impartial due process hearing before a hearing officer.

Hearing officer decisions must comply with certain standards regarding the provision of a FAPE and matters alleging procedural violations.

Parents may appeal to the state educational agency if they disagree with the local agency's decision.

Parents may bring a civil action in federal court if they disagree with the state's decision.

\author{
$\S 1415(b)(6)$ \\ $\S 1415(f)(1)(B$ \\ $\S 1415(f)(1)(A)$ \\ $\S 1415(f)(3)(E)(i)-(i i)$ \\ $\S 1415(\mathrm{~g})(1)$ \\ $\S 1415(i)(1) \& \S 1415(i)(2)(A)$
}

\section{Reimbursement of expenses}

Parents may be reimbursed for the cost of private school if the state fails to make a FAPE available for their child.

A prevailing party who is a parent of a child with a disability may be awarded attorneys fees. 
burden of persuasion as to the adequacy of the initial IEP should have been placed on the school district and remanded the case back to the ALJ (Brian S. v. Vance, 2000).

The school district appealed to the Fourth Circuit Court of Appeals, but, before the Fourth Circuit could hear the appeal, the ALJ ruled that, with the burden now on the school district, the district had failed to prove the adequacy of its IEP. The school district again appealed the ALJ's decision to the U.S. District Court, and the district court again placed the burden of persuasion on the school district (Weast v. Schaffer, 2002). The school district appealed to the Fourth Circuit Court of Appeals for a second time. The Fourth Circuit held that the district court erred in assigning the burden of proof to the school district and reversed the decision (Weast v. Schaffer, 2004).

\section{The Fourth Circuit}

In support of its decision to allocate the burden of persuasion to Brian's parents, the Fourth Circuit relied on what it referred to as the "normal rule": When a statute, such as IDEA, is silent as to the burden of persuasion, the burden is normally placed on the party initiating the proceeding and seeking relief (Weast v. Schaffer, 2004, p. 453). Because Brian's parents initiated the proceeding challenging his IEP, the burden of persuasion would be placed on them. The court recognized that the circuit courts of appeal disagreed as to which party assumed the burden of persuasion under IDEA; however, it was not persuaded by what it characterized as "little or no analysis" (p. 453) by those circuits that assigned the burden to the school districts. Therefore, the court declined to depart from the "normal rule" of allocating the burden of persuasion to the party seeking relief and placed the burden of persuasion on Brian Schaffer's parents (p. 453).

Brian's parents maintained that because of their greater expertise and resources, school districts have the natural advantage in IEP disputes and therefore should bear the burden of persuasion. The Fourth Circuit responded that Congress addressed this natural advantage by establishing procedural safeguards in IDEA to "level the playing field" (p. 453). The court also suggested that Congress could take remedial steps if experience shows that parents do not have access to sufficient expertise (p. 453). That is, Congress could amend IDEA. Table 4 shows the split decisions among the circuit courts.

\section{The Supreme Court}

Brian Schaffer's parents appealed to the U.S. Supreme Court. The Supreme Court granted certiorari to hear the case, and, on November 14, 2005, in a 6-2 decision, it affirmed the Fourth Circuit's decision placing the burden of persuasion on the parents challenging the IEP.

The Court explained that in a statutory cause of action, it would first look to the statute itself. If the statute was silent regarding which party had the burden, as was IDEA, the Court would begin with the "ordinary default rule that plaintiffs bear the risk of failing to prove their claims" (Mueller \& Kirkpatrick, 2003, p. 104).

Noting that decisions placing the entire burden of persuasion on the opposing party at the outset of a proceeding were extremely rare, the Supreme Court held that "absent some reason to believe that Congress intended otherwise ... we will conclude that the burden of persuasion lies where it usually falls, upon the party seeking relief' (Schaffer $v$. Weast, 2005, pp. 57-58).

\section{TABLE 4 \\ Circuits Split on the Burden of Persuasion pre Schaffer v. Weast (2005)}

\section{Burden on Parents}

Fourth Circuit

Fifth Circuit

Sixth Circuit

Tenth Circuit

Weast v. Schaffer, 377 F. 3d 449 (4th Cir. 2004).

Alamo Heights Independent School District v. State Board of Education, 790 F. 2d 1153 (5th Cir. 1986).

Cordrey v. Euckert, 917 F. 2d 1460 (6th Cir. 1990).

Johnson v. Independent School District No. 4, 921 F. 2d 1022 (10th Cir.1990).

\section{Burden on School District}

Second Circuit

Third Circuit

Eighth Circuit

Ninth Circuit

D.C. Circuit
Walczak v. Florida Union Free School District, 142 F. 3d 119 (2d Cir. 1998).

Carlisle Area School District v. Scott P., 62 F. 3d 520, (3d Cir. 1995).

E.S. v. Independent School District No. 196, 135 F. 3d 566 (8th Cir. 1998).

Clyde K. v. Puyallup School District No. 3, 35 F. 3d 1396 (9th Cir. 1994).

McKenzie v. Smith, 771 F. 2d 1527, 1532 (D.C. Cir. 1985). 
Justice O'Conner, writing for the majority, explained that the Court's ruling should be construed narrowly to the case at hand. The Court held:

The burden of proof in an administrative hearing challenging an IEP is properly placed upon the party seeking relief. In this case, that party is Brian, as represented by his parents. But the rule applies with equal effect to school districts: If they seek to challenge an IEP, they will in turn bear the burden of persuasion before an ALJ. (Schaffer $v$. Weast, 2005, p. 62)

\section{Ginsburg \& Breyer Dissent}

Though recognizing that courts ordinarily allocate the burden of proof to the initiating party seeking relief, Justice Ginsburg was persuaded that factors such as policy considerations, convenience, and fairness required that the burden of proof be assigned to the school district. She distinguished IDEA from typical civil rights legislation (e.g., the Americans with Disabilities Act), where parties must allege and prove discrimination or their qualification for statutory benefits, explaining that IDEA "casts an affirmative, beneficiary-specific obligation on providers of public education" designed to overcome past neglect and disregard encountered by children with disabilities seeking access (p. 64). Justice Ginsburg reasoned that school districts are charged with offering each student with a disability an IEP to meet his or her special needs; therefore, they should be called upon to demonstrate the adequacy of the IEP. She further argued that school districts are far better equipped to demonstrate that they have fulfilled their obligation under the IDEA than are the parents of students with disabilities to show that the schools have not met their obligations under the law. Justice Ginsburg pointed out that it is the school districts that are familiar with the services available and have experience with students with similar disabilities (p. 64) and that the majority of parents lack the knowledge and sophistication to mount an effective case against the district. Justice Ginsburg quotes Judge Luttig in his Fourth Circuit dissent: "In this setting, "the party with the bigger guns also has better access to information, greater expertise, and an affirmative obligation to provide the contested services"' (Weast $v$. Schaffer, 2004, p. 458, cited in Schaffer v. Weast, 2005, p. 67).

Justice Breyer argued in his dissent that, despite IDEA's detailed procedural scheme, the law is silent as to who bears the burden of persuasion in administrative hearings; therefore, Congress left it for the states to decide the issue. He also pointed to IDEA's provisions that assign the establishment of procedures for the hearing to the state and its agencies (20 U.S.C. $\$ 1415(f)(1)(A))$. Because the ALJ in Brian Schaffer's case looked for a federal rather than a state burden of persuasion, Justice Breyer would have remanded the case back to the ALJ to determine how Maryland administrative law would assign the burden of persuasion (Schaffer $v$. Weast, 2005, p. 71). In fact, Justice Ginsburg notes in her dissent that nine states submitted amicus curiae (friend of the court) briefs urging the Supreme Court to place the burden of persuasion on the school district, because to do so would best serve the purpose of IDEA (p. 66).

Justice Breyer submitted that should a lack of uniformity among the states become problematic, the U.S. Department of Education could promulgate a uniform federal standard, thereby limiting state choice. In support of allowing the state's ALJ to determine how state administrative procedures and state laws would apply the burden, Justice Breyer emphasized Congress's representation of IDEA as an exercise in "cooperative federalism" (pp. 70-71).

Justice O'Conner, writing for the majority, recognized that several state laws or regulations sought to override the default rule. The Court, however, did not address whether states may override the rule and put the burden of persuasion on the school districts, because no such state law existed in Maryland at the time. The Court also declined to address Justice Breyer's contention in his dissent that the states should decide how to allocate the burden of persuasion, because no such argument was presented by either party (pp. 61-62).

\section{The Burden Post-Schaffer}

Since the U.S. Supreme Court decided Schaffer in 2005, Congress has not addressed the burden of persuasion in IDEA claims, and, in its final regulations implementing the 2004 IDEA amendments (effective August 14, 2006), the U.S. Department of Education declined to assign the burden of persuasion in due process hearings. Relying on the Schaffer decision, the Department of Education found that "since Supreme Court precedent is binding legal authority, further regulation in this area is unnecessary. In addition, we are not aware of significant questions regarding the burden of production that would require regulation" (71 Fed Reg. 46540, at 46706).

Post-Schaffer, some states have amended their laws or enacted new legislation to place the burden of persuasion on the school district or the parent. Such state-level determination is argued to be consistent with the holding in Schaffer and the spirit of cooperative federalism urged by Justice Breyer in his dissent (Freed, 2009). Freed submits that the Supreme Court may need to revisit the IDEA burden of persuasion issue, given the potential for a split in the circuits after federal courts interpret Schaffer in states that assign the burden to school districts by state law (2009, p. 125). For example, in M.M. v. Special School District No. 1 (2008), the Eighth Circuit held that the Supreme Court's decision in Schaffer and its earlier decision in School Board of Independent School District No. 11 v. Renollett (2006) preempted 
Minnesota law that placed the burden of persuasion in a due process hearing on the school district. Nevertheless, the Supreme Court declined to review that decision (certiorari denied in M.M. v. Special School District No. 1, 129 S. Ct. 452 (2008)). If necessary, Congress could amend IDEA to assign the burden of persuasion in due process hearings.

The desire to place the burden of persuasion in due process hearings on the school district may be stronger in those states where free or low-cost legal assistance for parents is practically nonexistent. Parents in such settings are forced to navigate alone an intimidating legal process replete with complicated procedures, legalese, and acronyms against school districts that are equipped with experience, expertise, and their own attorneys, that is, "the bigger guns" (Weast v. Schaffer, 2004, p. 458).

Parents today, faced with both the burden of persuasion and the school districts' "natural advantage" (Schaffer, 2005, p. 60), may need more than ever to depend on the strength of expert witnesses to prevail in a due process hearing. Parents who do prevail, however, cannot seek reimbursement for the cost of that expert's testimony (Arlington Central School District Board of Education v. Murphy (2006); Thomason, 2007). See section (4) Reimbursement of Expenses.

\section{Exhaustion of Administrative Remedies}

The IDEA procedural safeguards emphasized by the U.S. Supreme Court from Rowley (1982) to Winkelman (2007) include the right of parents to present a complaint if they object to the identification, evaluation, placement, or provision of a FAPE for their child $(\$ 1415(b)(6))$. After a preliminary meeting for parents to discuss their complaint and for the local educational agency to attempt to resolve the matter, if an agreement is not reached, parents may proceed to an impartial due process hearing before a hearing officer ( $\S \S$ $1415(\mathrm{f})(1)(\mathrm{A}) \&(\mathrm{~B}))$. Parents who disagree with the hearing officer's decision may appeal to the state educational agency $(\S 1415(\mathrm{~g})(1))$. Some states, however, have only a one-tiered due process hearing system. Only after the administrative process is complete may parents who disagree with the state's decision file a civil action in court $(\$ 1415(\mathrm{i})(1)$ \& $\S 1415(\mathrm{i})(2)(\mathrm{A}))$.

\section{REPRESENTING YOURSELF IN COURT- WINKELMAN V. PARMA CITY SCHOOL DISTRICT (2007)}

Once parents exhaust the administrative remedies available to them under the IDEA, they may file a civil action in state court or federal district court $(\$ 1415(1)(2)(\mathrm{A}))$. The Supreme Court in Winkelman v. Parma City School District (2007) ruled that parents can pursue their own claims in federal court without an attorney because they possess procedural, reimbursement, and substantive rights under IDEA, in other words, the right to a FAPE for their child (p. 533).

Although the decision was hailed as a victory for parental rights under the IDEA, as Mead and Paige suggested, in practice it "may turn out to be something of a hollow victory" if parents going up against experienced school district attorneys lose more often than they win (Mead \& Paige, 2008). In fact, parents of children receiving special education and related services typically do not possess the knowledge and ability necessary to effectively advocate for their children on their own (Phillips, 2008; Wakelin, 2008). Furthermore, the Supreme Court's Schaffer v. Weast (2005) decision places the burden of persuasion on parents when they do seek relief. The current fee-shifting provisions of IDEA open up the possibility that the parents could be held responsible for the district's attorneys' fees (\$1415(i)(3)(B) (i)(III)). And the Supreme Court has determined that parents cannot recoup their expert witness fees when they do prevail in an IDEA action (Arlington v. Murphy, 2006). See section (4) Reimbursement of Expenses. Moreover, when the Supreme Court declined to address the Winkelmans' alternative argument that IDEA gives parents the right to prosecute claims (without an attorney) on their child's behalf (p. 535), the Court may have created an area of uncertainty for parents pursuing a FAPE for their child (Hagdorn, 2009; Kerr, 2009).

\section{(4) REIMBURSEMENT OF EXPENSES}

In Schaffer v. Weast (2005), the Supreme Court placed the burden of persuasion in due process hearings on the party seeking relief-typically the parent (Schaffer, 2005, pp. 53-54). In doing so, the Court was not persuaded by what it described as the parents' "most plausible argument"- that considerations of fairness require that the burden not be placed on a party to establish "facts peculiarly within the knowledge of his adversary," the school district (Schaffer, 2005, p. 60). Justice O'Conner explained that Congress addressed the "natural advantage" of school districts in information and expertise by requiring them to safeguard the procedural rights of parents and to share information with them (p. 60); therefore parents are "not left to challenge the government without a realistic opportunity to access the necessary evidence, or without an expert with the firepower to match the opposition" (p. 61). However, soon after its decision in Schaffer, the Supreme Court ruled in Arlington Central School District Board of Education v. Murphy (2006) that the costs recoverable by the prevailing party under IDEA do not include the payment of expert witness fees. For parents who typically bear the burden of persuasion in IDEA actions, the Supreme Court may have further diminished their bargaining strength (Mead \& Paige, 2008). 


\section{Arlington Central School District Board of Education} v. Murphy (2006)

Pearl and Theodore Murphy prevailed in their IDEA action seeking to require the Arlington Central School District Board of Education to pay for their son Joseph's private school tuition. The Murphys requested reimbursement for the fees they paid an educational consultant to assist them with their IDEA action. The U.S. District Court for the Southern District of New York found that the Murphys were entitled to compensation for $\$ 8,650$ in expert fees pursuant to the fee shifting provision of IDEA. Section 1415(i)(3)(B) provides for "reasonable attorneys' fees as part of the costs" to prevailing parents. The school district appealed the attorneys' fee award to the Second Circuit Court of Appeals. Recognizing that the Circuits disagreed regarding expert fees, the Second Circuit found that when Congress added the attorneys' fees provision in 1986, it intended to include expert fees as part of a prevailing party's costs (Murphy v. Arlington Central School District Board of Education, 2005). Table 5 shows the split decisions among the circuit courts.

\section{The Supreme Court}

The U.S. Supreme Court granted certiorari "to resolve the conflict among the Circuits with respect to whether Congress authorized the compensation of expert fees to prevailing parents in IDEA actions" (Arlington Central School District Board of Education v. Murphy, 2006, p. 295). The Court held that it does not (p. 304). Writing for the Majority, Justice Alito reasoned that because IDEA was enacted pursuant to the Spending Clause of the U.S. Constitution (Art. I, § 8, cl. 1), which allows Congress to impose conditions upon states accepting federal funds, there must be "clear notice regarding the liability at issue," or that expert fees may be awarded under the Act (Arlington v. Murphy, 2006, p. 297). The Supreme Court determined that the Act failed to provide such notice by use of the word "costs." The Court was not persuaded by the Murphys argument that Congress intended to include expert fees as part of the "costs" incurred by the prevailing parent, as evidenced by the language the Conference Committee used in its report upon passage of the bill:

\footnotetext{
The conferees intend that the term 'attorneys' fees as part of the costs' include reasonable expenses and fees of expert witnesses and the reasonable costs of any test or evaluation which is found to be necessary for the preparation of the parent or guardian's case in the action or proceeding, as well as traditional costs incurred in the course of litigating a case. (H.R. Conf. Rep. No. 99-687, at 5, 1986)
}

Justice Alito wrote "legislative history is simply not enough"; the key is not what a majority of both Houses intended, but what they put in the text of the law (p. 304).

The Majority was also not convinced by the Murphys' contention that to include expert fees as part of the costs to prevailing parents would further the goals of IDEA-to ensure that all children with disabilities have available to them a FAPE and that the rights of parents to challenge school district decisions are safeguarded. Justice Alito responded that IDEA is not intended to further such goals in all instances "at the expense of fiscal considerations" (p. 303).

\section{The Dissent}

Justice Breyer wrote for the Dissent that there are "two strong reasons to interpret the phrase in the IDEA to include expert fees: (1) that it was what Congress intended; and (2) that it furthers the purposes defined in the IDEA" (p. 309). Justice Breyer details the legislative history of the addition of the attorneys' fees provision in IDEA, quoting the language of the Conference Report. He then stresses that the goals of IDEA encourage parent participation, stating that "the practical significance of the Act's participatory rights and procedural protections may be seriously diminished if parents are

\section{TABLE 5}

Circuits Split on Expert Fees pre Arlington v. Murphy (2006)

\section{Burden on Parents}

Circuit Citation Ruling

Second Circuit

District of Columbia

Eighth Circuit
Arlington v. Murphy, 402 F. 3d 332 (2d Cir. 2005).

Goldring v. District of Columbia, 416 F. 3d 70 (DC Cir. 2005).

Neosho R-V School Dist. v. Clark ex rel. Clark, 315 F. 3d 1022

(8th Cir. 2003).
Expert fees allowed

Expert fees NOT allowed

Expert fees NOT allowed

Expert fees NOT allowed 
unable to obtain reimbursement of the costs of their experts" (pp. 313-314). Justice Breyer pointed to studies that show both the necessity of experts in IDEA cases and the inability of parents of children with disabilities to afford such fees. He also noted that many of the experts used by school districts are already on their staff but that, without potential reimbursement, parents may have to do without. Justice Breyer stated that the Majority decision to bar reimbursement for expert fees under IDEA "will leave many parents and guardians 'without an expert with the firepower to match the opposition,'- a far cry from the level playing field that Congress envisioned" (pp. 315-316, quoting the Court in Schaffer).

\section{Ginsburg Concurs}

Justice Ginsburg agreed with the result but disagreed with the Majority's "repeated references to a Spending Clause derived 'clear notice' requirement," noting that IDEA was also enacted pursuant to Section 5 of the Fourteenth Amendment. Justice Ginsburg quoted the Supreme Court's own language in Smith v. Robinson (1984) that the EAHCA (now IDEA) was "set up to aid states in complying with their constitutional obligations to provide a public education for handicapped children" (p. 305, quoting Smith v. Robinson, 1986, p. 992). Stating that the Court's "clear notice" "prop" was unnecessary given its own precedent and the text of IDEA (p. 306), Justice Ginsburg concluded that "the ball ... is properly left in Congress' court" (p. 307).

\section{THE IDEA FAIRNESS \& RESTORATION ACT}

The IDEA Fairness \& Restoration Act was introduced in the House on June 4, 2009, as HR 2740. The Act would override the Supreme Court's decision in Arlington v. Murphy (2006) by amending IDEA to allow parents to recover expert witness costs for due process hearings and civil actions under IDEA. According to the Council of Parent Attorneys and Advocates (COPAA), who filed an amicus brief with the Supreme Court in the Arlington v. Murphy appeal, the IDEA Fairness \& Restoration Act would align IDEA with other civil rights legislation, such as the Americans with Disabilities Act and Title VII of the Civil Rights Act, which allow prevailing plaintiffs to recover their expert fees. The group also pointed to the Government Accountability Office (GAO) study in 2003 that reported only five hearings per 10,000 special education students in 2003 along with the fact that parents must prevail to recover their costs (COPAA, 2009). Introduced by Representative Van Hollen from Maryland on June 4, 2009, HR 2740 was referred to the House Subcommittee on Early Childhood, Elementary, and Secondary Education on July 23, 2009 (THOMAS, Library of Congress).
When parents request a due process hearing to challenge the provision of a FAPE for their child, school districts undoubtedly submit their experts' opinions in support of their position. The Second Circuit in Murphy v. Arlington (2005) described expert testimony as "often critical in IDEA cases, which are fact-intensive inquiries about the child's disability and the effectiveness of the measures that school boards have offered to secure a free appropriate public education" (p. 338). In interpreting the IDEA fee shifting provision to exclude expert fees in Arlington v. Murphy (2006), the Supreme Court did not question the necessity of expert testimony for parents to mount a successful challenge to a school district's decision. In fact, in Schaffer $v$. Weast (2005), when placing the burden of persuasion on parents requesting a due process hearing, the Court acknowledged the significance of expert testimony (p. 61). In Schaffer $v$. Weast (2005), the Court affirmed the Fourth Circuit's decision to place the burden on the party seeking relief, which specifically addressed the necessity for experts:

\footnotetext{
For regardless of which side has the burden of proof in an administrative hearing, parents will have to offer expert testimony to show that the proposed IEP is inadequate. Shifting the burden of proof, in other words, will not enable parents by themselves to mount a serious, substantive challenge to an IEP. Congress recognized that parents need professional assistance, and the IDEA therefore allows parents who prevail in due process hearings to recover their fees for hiring lawyers. 20 U.S.C. $\$ 1415$ (i)(3). If experience shows that parents do not have sufficient access to substantive expertise under the current statutory scheme, Congress should be called upon to take further remedial steps. (Weast v. Schaffer, 2004, p. 456)
}

An additional consideration was presented by the National Disability Rights Network and the Center for Law and Education in their amicus brief in Arlington v. Murphy (2006). The groups submitted that the need for experts was increased by the 2004 IDEA amendments now requiring special education to be "based on peer-reviewed research to the extent practicable" $(\S 1414(\mathrm{~d})(1)(\mathrm{A})(\mathrm{i})(\mathrm{IV}))$; therefore, parents must submit evidence of educational options, research on generally accepted methodologies, and whether the proposed program is accepted and recognized as reasonable by educational experts (Brief, 2006, p.11). Experience may in fact show the necessity for Congressional action.

\section{Forest Grove School District v. T.A. (2009)}

After struggling in school since kindergarten, T.A. was evaluated by a school psychologist in his freshman year of high school. A school psychologist evaluated him and determined that T.A. was not eligible for special education services. With help from his family, T.A. completed his sophomore year, but his problems worsened. A private professional diagnosed T.A. with ADHD and a number of disabilities 
relating to learning and memory and recommended a structured residential learning environment. His parents enrolled T.A. in private school, notified the school district of their placement, and requested a due process hearing regarding his eligibility for special education services. The school district again evaluated T.A. and concluded that he was not eligible for special education services because his ADHD "did not have a sufficiently significant impact on his educational performance" (Forest Grove v. T.A., 2009, p. 2489). Because the school district determined that T.A. was not eligible for special education, they did not offer him an IEP.

After hearing testimony from numerous expert witnesses, the hearing officer found that T.A. was eligible for special education services; that the school district failed to identify him as eligible and failed to offer T.A. a FAPE; that the private school placement was appropriate; and that the school district was responsible for reimbursing T.A.'s parents for his private school tuition (Forest Grove v. T.A., 2009). The school district appealed and the U.S. District Court for the District of Oregon set aside the reimbursement award, ruling that the new 1997 statute $(\S 1412(\mathrm{a})(10(\mathrm{C})(\mathrm{ii}))$ prevented reimbursement for students who had not previously received special education and related services (Forest Grove v. T.A., 2005).

The Ninth Circuit Court of Appeals reversed the district court's decision, finding that students who had not previously received special education services through the public school were eligible for private school tuition reimbursement just as they were before the 1997 IDEA amendments as "appropriate" relief under $\S 1415(1)(2)(C)$ and that the new statute (IDEA $\S 1412(\mathrm{a})(10)(\mathrm{C})$ ) did not apply (Forest Grove v. T.A., 2008, pp. 1087-1088).

The U.S. Supreme Court granted certiorari to settle a split in the federal circuits (See Table 6) "to determine whether $\S 1412(a)(10(C)$ establishes a categorical bar to tuition reimbursement for students who have not previously received special education services under the authority of a public education agency" (Forest Grove, 2009, p. 2490). In a 6-3 decision, the Supreme Court held that it does not. Noting that the Burlington and Carter cases involved the adequacy of the proposed IEP, whereas in T.A.'s case the school district failed to provide an IEP at all, the Majority found the differences "insignificant." The Court explained that its analysis in Burlington and Carter depended not on the "particular facts of the case," but on the "language and purpose of the Act" itself (Forest Grove, 2009, p. 2491). The Court considered failing to propose an IEP to be just as serious as failing to provide an adequate one; therefore, the same reasoning applied. The only question was the effect, if any, of the 1997 IDEA amendments.

The Supreme Court found that the 1997 amendments to IDEA did not alter the text of $\$ 1415(1)(2)(C)$ (iii), which it previously held in Burlington gives courts broad authority to grant "appropriate" relief and that $\S 1412(a)(10)(C)$ did not affect its meaning. To read otherwise, the Court found, would be contrary to the Act's purpose of providing all children with disabilities with a FAPE and IDEA's "child find" obligation to identify, locate, and evaluate all children with

\section{TABLE 6}

\section{Circuits Split on tuition reimbursement unless a student previously received special education services pre Forest Grove v. T.A.}

\begin{tabular}{ll}
\hline Circuit & Citation \\
\hline Second Circuit & $\begin{array}{c}\text { Bd. of Educ. v. Tom F., 2006 U.S. App. LEXIS } 20961 \\
\text { (2d Cir. 2006) }\end{array}$ \\
Second Circuit & $\begin{array}{l}\text { Frank G. v. Board of Ed. of Hyde Park, 459 F. 3d } 356 \\
\text { (2d Cir. 2006) }\end{array}$
\end{tabular}

Eleventh Circuit

M. M. v. School Bd. of Miami-Dade Cty., Fla., 437 F. 3d 1085, 1099 (11th Cir. 2006)

First Circuit

\section{Ruling}

$\S 1412(a)(10)(C)(i i)^{*}$ does not bar
reimbursement

$\S 1412(a)(10)(C)(i i)$ does not bar reimbursement

$\S 1412(a)(10)(C)(i i)$ bars reimbursement

$\S 1412(a)(10)(C)(i i)$ bars reimbursement

Note. In the IDEA Amendments of 1997, reimbursement was not allowed unless a child has "previously received special education or related services under the [school's] authority" (IDEA, § 1412(a)(10)(C)(ii)). 
disabilities. The Court felt that excusing school districts that refused to find children eligible for special education "would produce a rule bordering on irrational" (pp. 2494-2495).

The school district maintained that it was entitled to notice under the Spending Clause. The Court, however, distinguished its holding in the Arlington v. Murphy (2006) expert fees case, noting that districts accepting IDEA funds expressly agree to provide a FAPE to all children with disabilities and, furthermore, that states have been on notice that IDEA authorizes reimbursement for private school tuition since its decision in Burlington (1985).

The Court also rejected as "unfounded" the financial burden argument of both the school district and the dissent that parents would be encouraged to enroll their children in private school without cooperating with school districts ( $p$. 2496). In doing so, the Supreme Court outlined the criteria for private school tuition reimbursement under IDEA: A court or hearing officer must conclude that the school district failed to provide a FAPE and that the private school placement was proper under the Act and must consider all relevant factors in determining the amount of reimbursement, including the notice provided by the parents and the school district's opportunity to evaluate the child. In fact, subsection (iii) of $\S 1412(\mathrm{a})(10)(\mathrm{C})$ entitled "Limitation on Reimbursement," specifically allows for a reduction in the amount reimbursed for the cost of private school when parents do not provide proper notice of the private school placement or do not cooperate with the school in evaluating the child.

The Supreme Court therefore concluded that, given these criteria, reimbursement for the cost of private school special education services may be awarded under IDEA "regardless of whether the child previously received special education or related services through the public school" (p. 2496).

\section{CONCLUSION}

In its latest special education decision, the Supreme Court in Forest Grove v. T.A. (2009) emphasized the responsibility of school districts to identify and evaluate students who may require special education and related services. The situation addressed by the Court in Forest Grove also further illustrates the necessity of effective communication and cooperation between school district personnel and parents in accomplishing IDEA's purpose-to provide a free appropriate public education for all children with disabilities.

Twenty-five years later, it has been argued that the explicit purpose of the current IDEA has outgrown the Rowley decision and that, given the unlikelihood that the U.S. Supreme Court will revisit the meaning of appropriate, the U.S. Department of Education should provide a clear federal definition of appropriate in its implementing regulations (Blau, 2007). Congress has not sought to define appropriate per se in its amendments to IDEA, nor did the Department of Education do so in its final regulations implementing IDEA's 2004 amendments (71 Fed Reg. 46540, at 46706).

Short of a legislative attempt at clarifying the meaning of appropriate, however, the 2007 U.S. Supreme Court's holding in Winklelman v. Parma City School District that parents have independent, enforceable rights under IDEA has been hailed as both a victory for parental rights and as an expansion or refinement by the Court of the definition of a FAPE (Yell et al., 2009; Wright \& Wright, 2007). The Winkelman decision has been described as the "pendulum swinging back to protect parents" by the Supreme Court returning to the "roots of the IDEA" (Wright \& Wright, 2007).

\section{REFERENCES}

Arlington Central School District Board of Education v. Murphy, 548 U.S. 291 (2006).

Blau, A. (2007). The IDEIA and the right to an "appropriate: education. BYU Education and Law Journal, 2007, 1-22.

Black's Law Dictionary (9th ed.). (2009). St. Paul, MN: West.

Board of Education of Hendrick Hudson Central School District v. Rowley, 458 U.S. 176 (1982).

Brian S. v. Vance, 86 F. Supp. 2d 538 (D. Md., 2000).

Brief for the National Disability Rights Network and the Center for Law and Education as Amici Curiae in Support of Respondents (2006). Retrieved from http://www.ndrn.org/amicus/briefs/0603 edu_Murphy.pdf

Burlington v. Department of Education, 471 U.S. 359 (1985).

Carter v. Florence County School District, 950 F2d 156 (4th Cir. 1991)

Cavanaugh v. Cardinal Local School District, 409 F.3d 753 (6th Cir. 2005).

Cedar Rapids Community School District v. Garret F., 526 U.S. 66 (1999).

Council of Parent Attorneys Advocates (COPPA). (2009). IDEA Fairness Restoration Act introduced: Restoring parents' rights to expert witness fees. Retrieved from http://copaa.org/news/IFRA_ intro_2009.html

Department of Education Regulations 34 C.F.R. pt. 300 and pt. 301 (2009).

Education for All Handicapped Children Act of 1975. Pub. L. No. 94142, 89 Stat.773 (1975).

Forest Grove School District v. T.A., 640 F. Supp. 2d 1320 (D. Or. 2005).

Forest Grove School District v. T.A., 523 F.3d 1078 (9th Cir. 2008).

Forest Grove School District v. T.A., 129 S.Ct. 2484 (2009).

Florence County School District Four v. Carter, 510 U.S. 7 (1993).

Freed, L. G. (2009). Cooperative federalism post-Schaffer: The burden of proof and preemption in special education. BYU Education and Law Journal, 2009, 103-130.

Gressman, G., Gell, K. S., Shapiro, S. M., Bishop, T. S., \& Hartnett, E. A. (2007). Supreme Court practice: For practice in the Supreme Court of the United States. Arlington, VA: BNA.

Hagdorn, P. C. (2009 (Student Comment). Winkelman v. Parma City School District: A major victory for parents or more ambiguity? Seton Hall Law Review, 39, 981-1021.

Handicapped Children Protection Act of 1986, Pub. L. No. 99-372, 100 Stat. 796 (1986). 


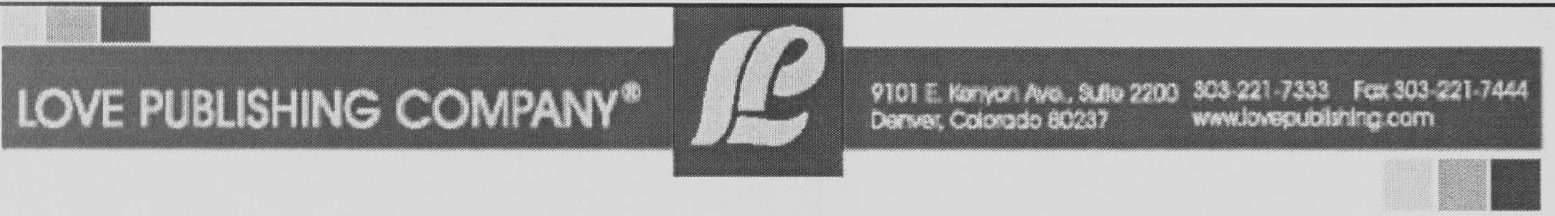

\title{
Qualitative Research Methods in Special Education
}

\author{
James Paul, Jeannie Kleinhammer-Tramill, and Kathleen Fowler
}

The history, theory, and methodology of each of eight different qualitative research methods is described by a researcher using it in the field. Each chapter is accompanied by a special education-related study that illustrates the method. This text demonstrates how qualitative research is particularly suited to investigating the experiences of students, teachers, school leaders, and families, as well as the meanings or attributions associated with those experiences. School culture, patterns of participation in school-related activities, and the impact of those

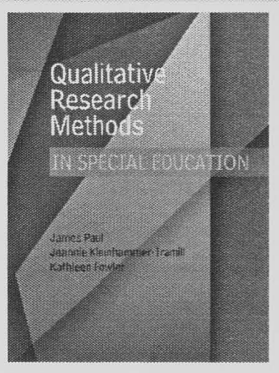
activities on a student's performance are among the phenomena that productively yield to qualitative approaches. The introductory chapter provides an overview of qualitative research methods and a historical perspective on applications in special education. The concluding chapter discusses the implications of qualitative research for improving practice and providing useful knowledge to inform policy and teacher education.

\section{Features:}

1. Introduction to eight qualitative research methods

2. Specific applications to special education

3. Published study illustrates each approach

\section{Contents}

Chapter 1: Overview

Chapter 2: Ethnographic Research

Chapter 3: Autoethnographic Research

Chapter 4: Narrative Research

Chapter 5: Oral History Research

Chapter 6: Case Study Research

Chapter 7: Grounded Theory Research

Chapter 8: Phenomenological Research .

Chapter 9: Action Research

Chapter 10: Integrating Strengths- and Problem-Based Assessment Information in Comprehensive Case Plans

Chapter 11: Concluding Reflection on Professional Education and Practice 
Honig v. Doe, 484 U.S. 305 (1988).

H.R. Conf. Rep. No. 99-687(1986).

Individuals with Disabilities Education Act of 1990, Pub. L. No. 101476, 104 Stat.110 (1990).

Individuals with Disabilities Education Act Amendments of 1997, Pub. L. No. 105-17, 111 Stat. 37 (1997).

Individuals with Disabilities Education Improvement Act of 2004, Pub. L. No. 108-446, 118 Stat. 2647(2004).

Individuals with Disabilities Education Act, codified, as amended at 20 U.S.C. $\$ \S 1400-1482$ (2006).

Irving Independent School District v. Tatro, 468 U.S. 883 (1984).

Kerr, S. (2009). Winkelman: Pro se parents of children with disabilities in the courts (or not?). Alaska Law Review, 26, 271-288.

Maroni v. Pemi-Baker Regional School District, 346 F.3d 247 (1st Cir. 2003).

McCormick, C. T. (1999) McCormick on evidence (3rd ed.). St. Paul, MN: West.

Mead, J. F., \& Paige, M. A. (2008). Parents as advocates: Examining the history and evolution of parents' rights to advocate for children with disabilities under the IDEA. Journal of Legislation, 34, 123-167.

M.M. v. Special School District No.1, 512 F.3d 455 (8th Cir. 2008).

M.M. v. Special School District No.1, 129 S. Ct. 452 (2008).

Mueller, C. B., \& Kirkpatrick, L. C. (2003). Evidence (3rd ed.). New York: Aspen.

Murphy v. Arlington Central School District Board of Education, 402 F. 3d 332 (2d Cir. 2005).

Phillips, E. (2008) (Student Note). When parents aren't enough: External advocacy in special education. Yale Law Journal, 117, 1802-1853.

Rule 11, Federal Rules of Civil Procedure.

Schaffer v. Weast, 546 U.S. 49 (2005).

School Board of ISD No. 11 v. Renollett, 440 F.3d 1007 (8th Cir. (2006).
Smith v. Robinson, 468 U.S. 992 (1984).

Spending Clause, U.S. Const. art. I, $\S 8$, cl. 1.

Supreme Court Rule 10, Considerations Regarding Review on Writ of Certiorari.

THOMAS (Library of Congress). HR 2740, IDEA Fairness \& Restoration Act, Retrieved from http://thomas.loc.gov/

Thomason, K. D. (2007). The costs of a "free" education: The impact of Schaffer v. Weast and Arlington v. Murphy on litigation under the IDEA. Duke Law Journal, 57, 457-486.

Town of Burlington v. Department of Education, 471 U.S. 359 (1985).

Wakelin, M. M. (2008). (Student Note and Comment). Challenging disparities in special education: Moving parents from disenfranchised team members to ardent advocates. Northwestern Journal of Law \& Social Policy, 3, 263-288.

Weast v. Schaffer, 240 F. Supp. 2d 396 (D. Md., 2002).

Weast v. Schaffer, 377 F. 3d 449 (4th Cir., 2004).

Winkelman v. Parma City School District, 550 U.S. 516 (2007).

Winkelman v. Parma City School District, 150 Fed. Appx. 406 (6th Cir. 2005).

Winkelman v. Parma City School District, 411 F.Supp. 2d 722 (N.D. Ohio 2005).

Wright, P., \& Wright, P. W. (2007). Supreme Court rules: Parents have independent, enforceable rights. Wrightslaw. Retrieved from http://www.wrightslaw.com/law/art/winkelman.pw analysis.htm

Wright. P. (n.d.). IDEA 2004: Rule 11 \& attorneys fees. Wrightslaw. Retrieved from http://www.wrightslaw.com/law/idea/attyfees.rule 11.htm

Yell, M. L., Katsiyannis, A., \& Hazelkorn, M. (2007). Reflections on the 25th anniversary of the U.S. Supreme Court's decision in Board of Education v. Rowley. Focus on Exceptional Children, 9 , $1-24$.

Yell, M. L., Ryan, J. B., Rozalski, M. E., \& Katsiyannis, A. (2009). The U.S. Supreme Court and special education: 2005-2007. Teaching Exceptional Children, 41(3), 68-75. 